Акушерство та гінекологія

УДК 61833-007.4.1.36.22

®С. Р. Галич, Д. М. Щурко, М. І. Щурко

Одеський національний медичний університет

\title{
ЕПІДЕМІОЛОГІЧНІ АСПЕКТИ ВРОДЖЕНИХ ВАД РОЗВИТКУ В ПІВДЕННОМУ РЕГІОНІ УКРАЇНИ
}

ЕПІДЕМІОЛОГІЧН АСПЕКТИ ВРОДЖЕНИХ ВАД РОЗВИТКУ В ПІВДЕННОМУ РЕГІОН УКРАЇНИ. Метою дОслідЖенНЯ був ретроспективний аналіз закономірності виникнення і розповсюдження вроджених вад розвитку (ВВР) плода в Південному регіоні України за 2010-2014 роки. Аналіз частоти свідчить про нерівномірне розповсюдження ВВР плода по областях Південного регіону на фоні зростання кількості пологів, високу частоту ВВР плода в міській місцевості в порівнянні з сільською та високий рівень питомої ваги ВВР плода в містах та селищах, розташованих в акваторіях Чорного та Азовського морів і річок Південний Буг та Дніпро. В структурі ВВР плода ведуче місце займають ВВР серцево-судинної системи, сечовивідної та кістково-м'язової систем. Встановлена сезонність ВВР плода.

ЭПИДЕМИОЛОГИЧЕСКИЕ АСПЕКТЫ ВРОЖДЕННЫХ ПОРОКОВ РАЗВИТИЯ В ЮЖНОМ РЕГИОНЕ УКРАИНЫ. ЦЕЛЬЮ исследования был ретроспективный анализ закономерности распространения врожденных пороков развития (ВПР) плода в Южном регионе Украины за 2010-2014 годы. Анализ частоты свидетельствует о неравномерном распространении ВПР по областям Южного региона на фоне роста частоты родов, высокой частоте ВПР плода В городской местности в сравнении с сельской и высоком удельном весе ВПР плода в городах и селах расположенных в акваториях Черного и Азовского морей, а также речек Южный Буг и Днепр. В структуре ВПР плода ведущее место занимают ВПР сердечно-сосудистой системы, мочевыделительной и костно-мышечной систем. Установлена сезонность ВПР плода.

EPIDEMIOLOGICAL ASPECTS OF CONGENITAL MALFORMATIONS IN THE SOUTHERN REGION OF UKRAINE. The aim of the study was a retrospective analysis of the patterns of distribution of the fetus congenital malformations (CM) in the southern region of Ukraine in 2010-2014. The frequency analysis indicates uneven distribution of CM by areas of the Southern Region against the background of increasing delivery rate, high frequency of the fetus $\mathrm{CM}$ in the urban areas compared to the rural areas and the high proportion of the fetus $\mathrm{CM}$ in towns and villages located in the Black and Azov seas and rivers Southern Bug and Dnieper. CMs of the cardiovascular, urinary and musculoskeletal systems take a leading place in the structure of the fetus CM. There was established the seasonality of the fetus CM.

Ключові слова: вагітність, вроджені вади розвитку, епідеміологія, ретроспективний аналіз.

Ключевые слова: беременность, врожденные пороки развития, эпидемиология, ретроспективный анализ.

Key words: pregnancy, fatal malformations, epidemiology, retrospective analyses.

ВСТУП. Кризова демографічна ситуація, що склалася в Україні, призвела до суттєвого скорочення кількості населення. На популяційному рівні демографічні процеси сприяють зниженню генетичної гетерогенності, скороченню репродуктивного та генетично-ефективного об'єму популяції, що порушує структуру генофонду [1].

До оцінки стану здоров'я популяції відносять показники здоров'я дітей та частоту розповсюдження вроджених вад розвитку [2, 3]. Вроджені вади розвитку являють собою проблему не тільки медицини, а й держави, оскільки їх лікування та інвалідність потребують великих матеріальних затрат [4]. Кількість вроджених вад розвитку в останні десятиліття помітно збільшилася, а питома вага спадкової та вродженої патології в структурі захворюваності й смертності новонароджених та дітей раннього віку продовжує зростати [5].

За даними ВООЗ, вроджені вади розвитку спостерігаються у 5,5 \% новонароджених та служать причиною смертності у 33-37 \% дітей 1 року життя, сприяють розвитку інвалідності у 40 \% дітей і являють собою гостру медичну проблему в європейських країнах [6].
За даними МОЗ України, щорічно народжується близько 10 тисяч дітей з вродженою патологією, 3 них до 20 тисяч стають інвалідами, втому числі близько 5 тисяч стають інвалідами через вроджені вади розвитку [7]. За останні роки в Україні частота вроджених вад розвитку сягає до 27,3 \% і займає одне 3 найперших місць у дитячій смертності (3,1\%), а серед дітей першого року життя складає 21,9 \% захворюваності та інвалідності [8]. Питома вага дітей 3 вродженими вадами розвитку серед дітей, які померли в ранньому віці, складає 25-30 \%. При цьому перинатальна летальність у містах в 1,5 раза більша, ніж у сільській місцевості $[9,10]$.

Етіологічні фактори, які призводять до формування вроджених вад розвитку, надзвичайно різноманітні та мінливі. Використання епідеміологічного підходу сумісно з клінічними методами дослідження в останні роки набуває особливої актуальності та визначає необхідність розробки профілактичних програм $з$ урахуванням територіальних особливостей патології. Аналіз структури та нозології летальності необхідний для планування об'єму діагностичних, лікувальних, реабілітаційних та профілактичних заходів [8]. 
МАТЕРІАЛИ ТА МЕТОДИ. Ретроспективне когортне епідеміологічне дослідження ВВР проведено в Південному регіоні України (Одеська, Миколаївська та Херсонська області) за 2010 - 2014 роки. Матеріалом для дослідження були «Повідомлення про народження дитини та обстеження на наявність вроджених вад розвитку, хромосомної та спадкової патології» (ф. №149-1,0), затверджені МОЗ України від 31.12.2003 р. № 641,84.

РЕЗУЛЬТАТИ ДОСЛІДЖЕННЯ ТА ЇХ ОБГОВОРЕННЯ. Питома вага ВВР в Україні протягом 20102013 років практично не змінилася і складає в се-

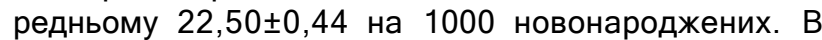
Південному регіоні України, в склад якого входять Одеська, Миколаївська та Херсонські області, протягом 2010-2014 років найвищий показник ВВР мала Херсонська область. При цьому середній показник за 5 років майже не відрізнявся від показників України, за винятком 2010 року, де питома вага ВВР склала 26,6 на 1000 новонароджених і мала достовірну різницю з показниками в Україні $(p<0,05)$. Одеська і Миколаївська області мали статистично меншу питому вагу ВВР протягом 20102014 років в порівнянні з державними показниками і складали в середньому 18,22 1 ,2 на 1000 новонароджених в Одеській області $(p<0,05)$ та $16,08 \pm 0,5$ в Миколаївській області $(p<0,05)$. Лише в 2010 році показник ВВР в Одеській області мав рівень державного (табл. 1).

Для порівняння динаміки поширеності BВР у міській та сільській місцевості була розрахована ча- стота вад розвитку народження живих малюків у містах та районних центрах Південного регіону. Аналіз результатів показав, що в Одеській та Херсонській областях частота ВВР у містах перевищувала цей показник у сільській місцевості, при цьому в Херсонській області більше, ніж в Одеській. Найнижчий показник ВВР спостерігався в Миколаївській області. Аналіз міських показників протягом 5 років спостереження показав, що вони не мали коливань, за винятком 2014 року в Одеській та Херсонській областях. У цьому році цей показник достовірно знизився в порівнянні 3 іншими роками.

У сільській місцевості показники ВВР були вищими в Херсонській та Миколаївських областях в порівнянні з Одеською областю і в кожній області протягом 5 років спостереження майже не мали коливань (табл. 2).

Дослідження ВВР в Одеському регіоні показало, що найбільша кількість ВВР спостерігається в м. Одеca $(33,2 \%)$, Біляївському $(9,4 \%)$, Б-Дністровському (6,3\%), Комінтернівському (5,5\%), Овідіопільському (5,3 \%) та Савранському районах (5,3 \%) (графік 1). Усі перераховані райони характеризуються значною щільністю населення, розташовані навколо обласного центру і мають вихід до річок, пов'язаних із Чорним морем. Незважаючи на значну урбанізацію, переважання населення молодого віку та розташування місцевості вздовж моря, показники ВВР в інших великих містах регіону були незначними: Іллічівськ $(3,7 \%)$, Южне $(0,9 \%)$.

Таблиця 1. Питома вага ВВР у Південному регіоні (на 1000 новонароджених)

\begin{tabular}{|l|c|c|c|c|c|c|}
\hline & 2010 рік & 2011 рік & 2012 рік & 2013 рік & 2014 рік & 3 а 5 років \\
\hline Україна & 21,15 & 22,8 & 22,9 & 23,5 & & $22,59 \pm 0,44$ \\
\hline Одеська область & 21,9 & $18,5^{*}$ & $17,1^{*}$ & $19,0^{*}$ & 14,6 & $18,22+1,2^{*}$ \\
\hline Миколаївська область & $15,09^{*}$ & $14,76^{*}$ & $17,56^{*}$ & $16,92^{*}$ & 15,26 & $16,08 \pm 0,5^{*}$ \\
\hline Херсонська область & $26,6^{*}$ & 22,6 & 21,97 & 24,9 & 23,77 & $23,97 \pm 0,83$ \\
\hline
\end{tabular}

Примітка. * - статистично достовірна різниця областей з показниками України.

Таблиця 2. Порівняльна характеристика ВВР у міській та сільській місцевості Південного регіону України

\begin{tabular}{|c|c|c|c|c|c|c|c|c|}
\hline Міста та райони & \multicolumn{2}{|c|}{ Роки } & 2010 & 2011 & 2012 & 2013 & 2014 & $\begin{array}{c}\text { За } 5 \text { років } \\
\text { спостереження }\end{array}$ \\
\hline \multirow[t]{3}{*}{ Одеська область } & пологи & абс. & 28566 & 31579 & 30384 & 28936 & 29475 & 148940 \\
\hline & міста & $\begin{array}{c}\text { абс. } \\
\text { на } 1000\end{array}$ & $\begin{array}{c}390 \\
13,65 \\
\end{array}$ & $\begin{array}{c}379 \\
12 \\
\end{array}$ & $\begin{array}{c}368 \\
12,11 \\
\end{array}$ & $\begin{array}{l}426 \\
14,7 \\
\end{array}$ & $\begin{array}{c}278 \\
9,4^{* *}\end{array}$ & $\begin{array}{c}1841 \\
12,4 \pm 0,8^{*}\end{array}$ \\
\hline & райони & $\begin{array}{c}\text { абс. } \\
\text { на } 1000\end{array}$ & $\begin{array}{r}139 \\
4,87\end{array}$ & $\begin{array}{l}161 \\
5,1\end{array}$ & $\begin{array}{l}150 \\
4,9\end{array}$ & $\begin{array}{l}124 \\
4,3\end{array}$ & $\begin{array}{l}157 \\
5,3\end{array}$ & $\begin{array}{c}731 \\
4,9+0,17\end{array}$ \\
\hline \multirow[t]{3}{*}{ Миколаївська область } & пологи & абс. & 12794 & 12869 & 13349 & 12939 & 12908 & 64859 \\
\hline & міста & $\begin{array}{c}\text { абс. } \\
\text { на } 1000\end{array}$ & $\begin{array}{l}92 \\
7,2\end{array}$ & $\begin{array}{l}84 \\
6,5\end{array}$ & $\begin{array}{l}104 \\
7,8\end{array}$ & $\begin{array}{l}112 \\
8,7\end{array}$ & $\begin{array}{c}107 \\
8,29^{* *}\end{array}$ & $\begin{array}{c}499 \\
7,7 \pm 0,39^{*}\end{array}$ \\
\hline & райони & $\begin{array}{c}\text { абс. } \\
\text { на } 1000\end{array}$ & $\begin{array}{l}101 \\
7,9\end{array}$ & $\begin{array}{r}106 \\
8,23\end{array}$ & $\begin{array}{l}112 \\
8,4\end{array}$ & $\begin{array}{r}100 \\
7,73\end{array}$ & $\begin{array}{c}91 \\
7,05\end{array}$ & $\begin{array}{c}510 \\
7,9 \pm 0,23\end{array}$ \\
\hline \multirow{3}{*}{ Херсонська область } & пологи & абс. & 12170 & 11872 & 13427 & 12014 & 11865 & 61348 \\
\hline & міста & $\begin{array}{c}\text { абс. } \\
\text { на } 1000\end{array}$ & $\begin{array}{l}269 \\
22,1\end{array}$ & $\begin{array}{l}301 \\
25,4\end{array}$ & $\begin{array}{l}280 \\
20,9\end{array}$ & $\begin{array}{c}300 \\
25\end{array}$ & $\begin{array}{c}117 \\
9,86^{* *}\end{array}$ & $\begin{array}{c}1267 \\
20,7 \pm 2,8^{*}\end{array}$ \\
\hline & райони & $\begin{array}{c}\text { абс. } \\
\text { на } 1000\end{array}$ & $\begin{array}{l}108 \\
8,9\end{array}$ & $\begin{array}{l}102 \\
8,6\end{array}$ & $\begin{array}{c}136 \\
10,1\end{array}$ & $\begin{array}{l}117 \\
9,7\end{array}$ & $\begin{array}{l}165 \\
13,9\end{array}$ & $\begin{array}{c}628 \\
10,24 \pm 0,8\end{array}$ \\
\hline
\end{tabular}

Примітки: * - статистично достовірна різниця між областями;

** - статистично достовірна різниця по роках. 


\section{Акушерство та гінекологія}

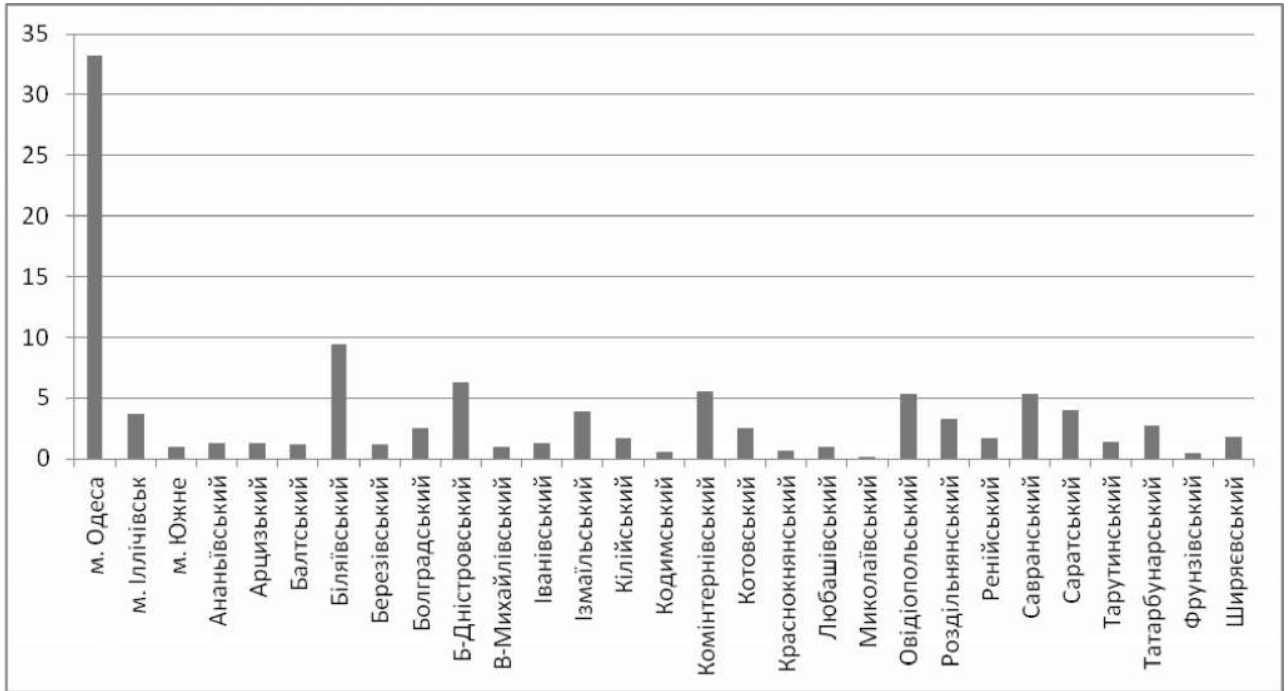

Графік 1. Частота ВВР в Одеській області за 2010-2014 роки.

У Миколаївській області ВВР найбільше спостерігалися в м. Миколаїв (5,95 \%), Вознесенському районі (2\%), Первомайському районі $(1,19 \%)$, Миколаївському $(0,95)$ та Жовтневому районах $(0,9 \%)$, що також разташовані навколо обласного центру та мають вихід на р. Південний Буг (графік 2).

У Херсонській області найбільша питома вага також належить обласному центру (61,6 \%). В інших містах та районах регіону ця складова нижча: в м. Н-Каховка - 4,5 \%, Білозерському районі - 3,5 \%, Бореславському - 3,3\%, Геніченському - 3,9 \%, Голопристанському - 3,5 \%, Скадовському - 3,5 \%, Цюрюпинському - 4,75. Всі ці міста та райони також мають вихід до р. Дніпра та Чорного і Азовського морів (графік 3).

Аналіз структури ВВР у Південному регіоні (графік 4) дозволив встановити, що перше місце займають ВВР серцево-судинної ситеми, причому їх питома вага найбільша в Одеській області $(38,3 \%$, р <0,05). На другому - ВВР сечовивідної системи і питома вага цих вад не має достовірної різниці між областями. На третьому - ВВР кістково-м'язової ситеми, які в Одеській та Миколаївських областях майже на одному рівні, і мають статистичну різницю з Херсонською областю $(7,3 \%, p<0,05)$. Четверте місце займають ВВР центральної нервової системи, які найвищі в Херсонській області $(10,9 \%, p<0,05)$. П'яте місце займають множинні ВВР, які найвищі в Миколаївському регіоні і складають 9 \% ( $p<0,001)$. Занепокоєння викликає частота синдрому Дауна в Херсонському регіоні, яка складає 5,9 \% і достовірно вища за інші регіони $(p<0,01)$.

Аналіз часових рядів з використанням методу сезонної композиції дозволив встановити переважання сезонної компоненти в січні, березні, травні, червні, вересні та листопаді (графік 5). Враховуючи, що переважне число ВВР формується в I триместрі вагітності, вочевидь, що тератогенні чинники впливали на ембріон впродовж лютого-квітня, червнясерпня та жовтня-листопада.

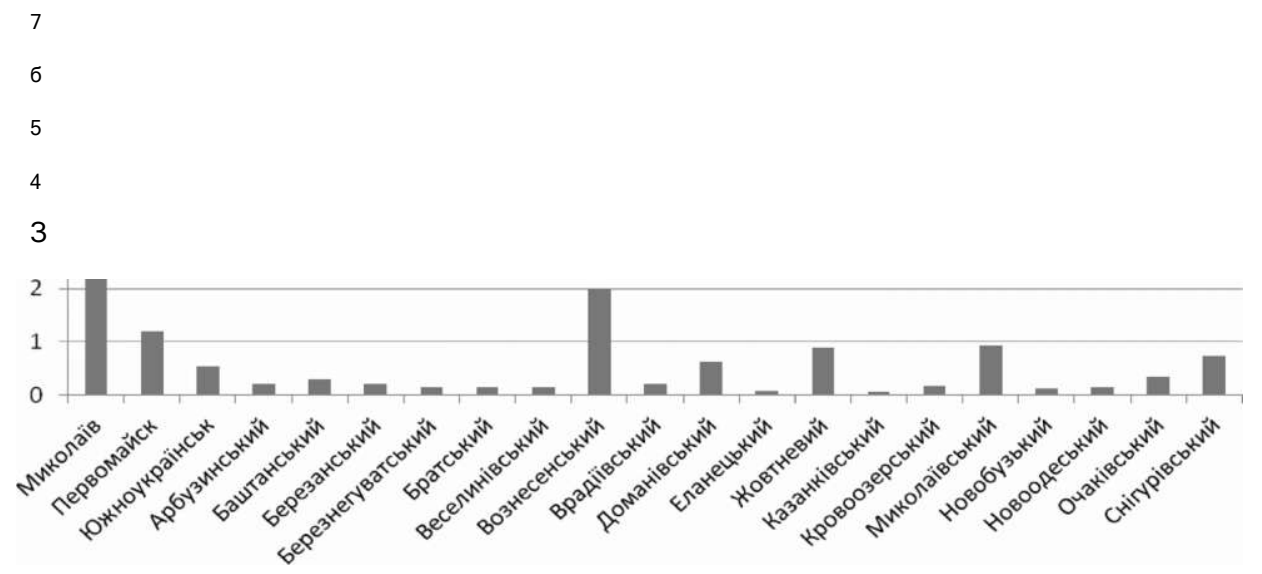

Графік 2. Частота ВВР у Миколаївській області за 2010-2014 роки. 


\section{Акушерство та гінекологія}

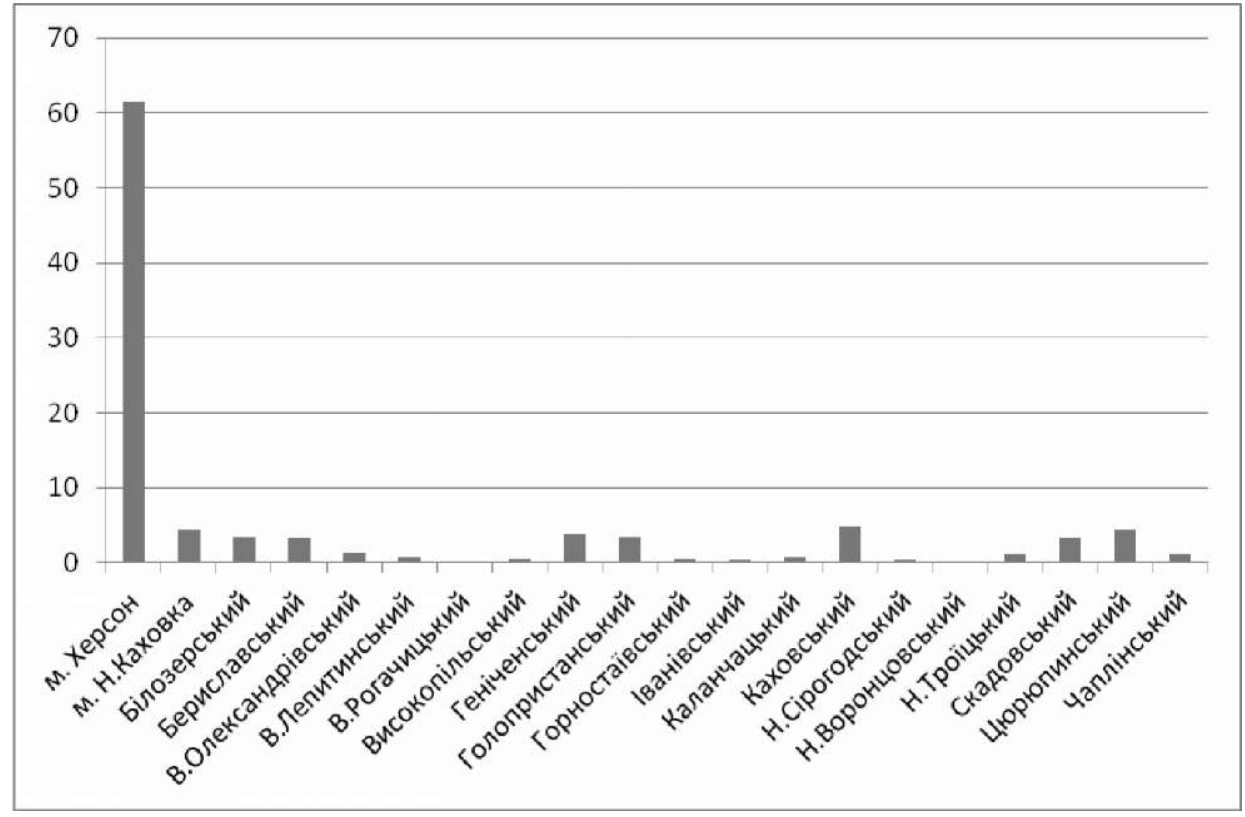

Графік 3. Частота ВВР у Херсонській області за 2010-2014 роки.

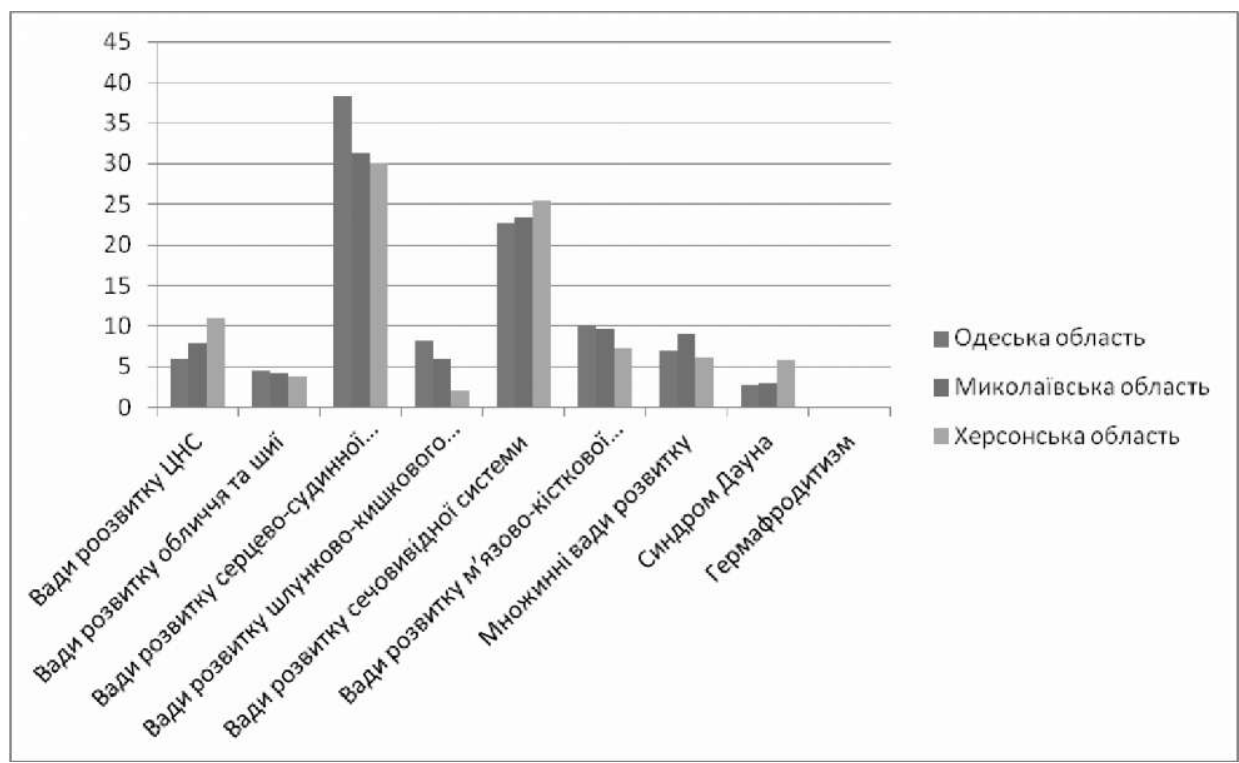

Графік 4. Структура ВВР у Південному регіоні.

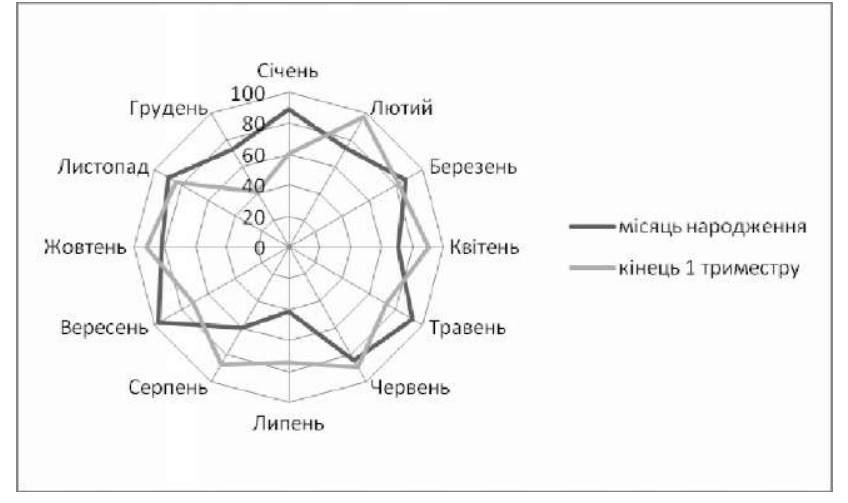

Графік 5. Сезонна частота ВВР.
ВИСНОВКИ. 1. На тлі рівномірного розподілу частоти ВВР в Україні за 2010-2014 роки Херсонська область має показники, порівнянні з державними, за винятком 2010 року, а Одеська та Миколаївська області мали меншу питому вагу в порівнянні з Україною.

2. Аналіз динаміки поширення ВBР у міській та сільській місцевості показав, що цей показник вищий у міській місцевості. Питома вага в сільській місцевості в Миколаївському та Херсонському регіонах вища від Одеського і мала рівномірний характер.

3. На тлі щорічного збільшення пологів у всіх областях високий рівень питомої ваги ВВР спостерігався в містах та районах всіх областей, що прилягають до Чорного, Азовського морів та річок Південний Буг і Дніпро. 


\section{Акушерство та гінекологія}

4. Аналіз структури ВВР у всіх областях показав, що перше місце займають ВВР серцево-судинної системи, друге - ВВР сечовивідної системи, третє ВВР м'язово-кісткової системи.

5. Встановлена залежність частоти ВВР від сезонної компоненти.
ПЕРСПЕКТИВИ ПОДАЛЬШИХ ДОСЛІДЖЕНЬ. ОТримані результати потребують подальшого вивчення екологічної ситуації в містах Південного регіону України для розробки і впровадження методів прогнозування ВВР плода. Особливо це стосується населених пунктів, які розташовані у водних акваторіях.

\section{СПИСОК ЛІТЕРАТУРИ}

1. Лановенко О. Регіональний моніторинг природжених вад розвитку в Херсонській області / О. Лановенко // Вісник Львівського університету. Серія біологічна. - 2014. - Вип. 64. - С. 177-183.

2. Мойсеєнко Р. О. Частота і структура захворюваності дітей в Україні та шляхи її зниження / Р. О. Мойсеєнко // Перинатологія та педіатрія. - 2009. - № 4. - C. 23-26.

3. Чайковська Г. С. Частота вроджених вад серця в структурі летальності новонароджених дітей та немовлят першого року життя / Г. С. Чайковська, О. 3. Гнатенко, О. Б. Куриляк // Международный журнал педиатрии, акушерства и гинекологии. - 2012. - T.2, № 2. - С. 5-8.

4. Ризик народження дитини з вродженою вадою розвитку як інтегральний показник якості пренатальної профілактики та діагностики патології в Україні / О. В. Линчак, Т. М. Поканєвич, О. В. Процюк [та ін.] // Гігієна населених місць. - 2011. - № 57. - С. 326 332.

5. Черненков Ю. В. Диагностика, профилактика и коррекция врожденных пороков развития / Ю. В. Черненков // Саратовский научно-медицинский журнал. - 2009. - Т. 5, № 3. - С.379-383.
6. Роль наследственных болезней и врожденных пороков развития в возникновении детской инвалидности и возможные меры профилактики / А. С. Симаходский, О. П. Романенко, Д. К. Верлинская, Е. Ю. Кузнецова // Вопросы практической педиатрии. - 2008. - Т. 3, № 4. - С.82-85.

7. Богатирьова Р. В. Генетико-демографічні процеси серед населення України / Р. В. Богатирьова, О. В. Линчак, О. І. Тимченко // Журнал НАМН України. - 2012. - T. 18, № 1. - С. 81-91.

8. Запорожан В. Н. Генетическая медицина / В. Н. Запорожан, В. А. Кордон, Ю. И. Бажора. - Одеса : Одесский государственный медицинский университет, 2008. - 432 с

9. Сорокман Т. В. Оцінка соціально-гігієнічних факторів ризику у виникненні природжених вад серцево-судинної системи / Т. В. Сорокман, Н. І. Підвисоцька, Н. О. Попелюк // Педіатрія, акушерство та гінекологія. - 2010. - № 73 (1). - С. 28-30.

10. Руденко I. В. Нозологічні форми та частота природжених пороків серцево-судинної системи у новонароджених Одещини / І. В. Руденко // Педіатрія, акушерство та гінекологія. - 2009. - № 72 (3). C. 47-48. 